\title{
Proteins and fibrinolysis in recipients of renal allografts
}

\author{
E. N. WARDLE, I. S. MENON, P. R. ULDALl, AND J. SWINNEY
}

From the Royal Victoria Infirmary, Newcastle upon Tyne

SYNOPSIS Studies of serum proteins, platelets, and fibrinolysis in patients after renal allografting show that a fall in plasma fibrinogen in the postoperative period can be associated with early rejection and that a rise in serum fibrin degradation products when accompanied by a fall in platelets is associated with rejection. Fibrinolysis is depressed in these patients until two months after transplantation and marked depression of fibrinolysis may precede rejection. The late coincidence of $\stackrel{N}{\perp}$ fibrinolytic depression with a rise in fibrin degradation products suggests chronic insidious rejection. 음

During renal allograft rejection platelet aggregates form in the glomerular capillaries and small arteries and in the absence of effective treatment become stabilized by fibrin and attached to damaged endothelium and eventually become incorporated into the arterial intima (Porter, 1967; Mustard, Evans, Packham, and Nishizawa, 1969). Rejection episodes after the tenth day are then characterized by fibrinoid necrosis of the vasculature. Less often frank thrombosis of the renal vessels may accompany immediate rejection resulting from blood group incompatibility or presensitization of the donor (Porter, Dossetor, Marchioro, Peart, Rendall, Starzl, and Terasaki, 1967).

Under any of these circumstances changes in peripheral blood platelets, fibrinogen, reactive proteins, and fibrinolysis might be evident. We have made detailed studies of these factors over a period of the four weeks following transplantation in nine patients and some less detailed studies in another five. There are also long-term follow-up observations on 12 patients.

\section{Methods}

Before operation and on three days a week thereafter estimations were made of platelet counts, plasma fibrinogen (Ratnoff and Menzie, 1951), fibrin monomer (Lipiński, Worowski, Jeljaszewicz, Niewiarowski, and Rejniak, 1968), euglobulin lysis time (von Kaulla, 1963, modified by Menon), fibrinolytic inhibitors of urokinase (McNichol, Gale, and Douglas, 1962), and serum fibrin degradation products using the Burroughs Wellcome kit. (The Received for publication 18 June 1970. blood was collected in tubes containing trasylol and $\stackrel{\widehat{\partial}}{\frac{T}{2}}$ was clotted with thrombin.) In addition, $\operatorname{serum} \overrightarrow{0}$ proteins were measured by radial diffusion in agar $\stackrel{-}{-}$ plates containing specific antisera against $\alpha$ l-antitrypsin, $\alpha$ l-acid glycoprotein and orosomucoid as typical reactant proteins, and against $\alpha 2$-macroglobulin, immunoglobulin IgM and $\beta 1 C / \beta 1 A$ comple-ō ment. These estimations were made without $\frac{0}{\circ}$ knowledge of the clinical course of the patient, which 2 was being assessed independently by the clinician $\vec{O}$ (P.R.U.) using standard clinical and biochemical $\Xi$ criteria.

The clinical criteria for rejection were swelling, pain, and tenderness of the graft accompanied by malaise, fever, tachycardia, hypertension, and:decrease in urine output. Some or all of these signs 3 were present in all cases and were supported by ao rise in serum creatinine and a fall in urine urea excretion. Rejection was harder to diagnose in patients receiving cadaver grafts with poor initial? function due to ischaemia. Renal biopsy was employed in selected cases, especially in those receiving cadaver grafts in which it was difficult too decide whether rejection had been adequately treated.

Analysis of the results was further complicated ${ }^{\omega}$ because some patients had bilateral nephrectomye and splenectomy at the same time, and consequentlye more trauma to tissue. The results were compared with estimations on two patients who underwent total colectomy for ulcerative colitis. A brief: synopsis of the patients is given in Table I togetherd with their record of rejection episodes. One patien (J.L.) had a second graft after an early technica $\mathbb{R}$ failure, eight patients had early rejection episodes 


\begin{tabular}{|c|c|c|c|c|c|}
\hline Patient & Age (yr.) & Operation & Type of Graft & Ischaemic Damage & Fate \\
\hline $\begin{array}{ll}1 & \text { L.C. } \\
2 & \text { T.L. } \\
3 & \text { I.M. } \\
4 & \text { J.L. } \\
5 & \text { J.L. } \\
6 & \text { J.S. } \\
7 & \text { M.L. }\end{array}$ & $\begin{array}{l}12 \\
25 \\
23 \\
36 \\
36 \\
38 \\
36\end{array}$ & $\begin{array}{l}\text { Nephrectomy and splenectomy } \\
\text { Simple } \\
\text { Nephrectomy and splenectomy } \\
\text { Nephrectomy and splenectomy } \\
\text { Simple } \\
\text { Nephrectomy or splenectomy } \\
\text { Nephrectomy or splenectomy }\end{array}$ & $\begin{array}{l}\text { Living donor } \\
\text { Cadaver } \\
\text { Living donor } \\
\text { Living donor } \\
\text { Cadaver } \\
\text { Living donor } \\
\text { Cadaver }\end{array}$ & $\begin{array}{l}0 \\
+ \\
+ \\
- \\
+ \\
0 \\
+\end{array}$ & $\begin{array}{l}\text { Rejection at } 1 \text { day } \\
\text { Rejection at } 3 \text { wk } \\
\text { Rejection at } 2 \text { days, myositis at } 3 \text { mth } \\
\text { Technical failure } \\
\text { Late hepatitis, death } \\
\text { Late pulmonary embolus, death } \\
\text { Acute tubular necrosis at } 2 \text { days, rejection } \\
\text { at } 6 \text { days } \\
\text { Rejection at } 4 \mathrm{mth} \text {, rejection at } 6 \mathrm{mth}\end{array}$ \\
\hline $\begin{aligned} 8 & \text { E.W. } \\
9 & \text { I.M. } \\
10 & \text { J.M. } \\
11 & \text { K.W. } \\
12 & \text { G.H. } \\
13 & \text { R.W. } \\
14 & \text { J.M. }\end{aligned}$ & $\begin{array}{l}23 \\
26 \\
24 \\
31 \\
23 \\
15 \\
27\end{array}$ & $\begin{array}{l}\text { Simple } \\
\text { Nephrectomy and splenectomy } \\
\text { Simple } \\
\text { Simple } \\
\text { Nephrectomyal and splenectomy } \\
\text { Nephrectomy and splenectomy } \\
\text { Nephrectomy and splenectomy }\end{array}$ & $\begin{array}{l}\text { Cadaver } \\
\text { Cadaver } \\
\text { Cadaver } \\
\text { Living donor } \\
\text { Living donor } \\
\text { Living donor } \\
\text { Living donor }\end{array}$ & $\begin{array}{l}+ \\
+ \\
+ \\
0 \\
0 \\
0 \\
0\end{array}$ & $\begin{array}{l}\text { Rejection at } 10 \text { days, rejection at } 6 \text { wk } \\
\text { Renal cortical necrosis at } 12 \text { days } \\
\text { Rejection at } 4 \text { days } \\
\text { Renal cortical necrosis } \\
\text { Rejection at } 3 \text { days } \\
\text { Rejection at } 2 \text { wk } \\
\text { Rejection at } 2 \text { days }\end{array}$ \\
\hline
\end{tabular}

Table I Summary of patients studied

\begin{tabular}{|c|c|c|c|c|c|c|c|c|}
\hline Patient & Fibrinogen & Fibrin Monomer & $\begin{array}{l}\text { Fibrin Degradation } \\
\text { Products }\end{array}$ & $\begin{array}{l}\text { Fibrinolytic } \\
\text { Inhibitors }\end{array}$ & $\begin{array}{l}\text { Euglobulin } \\
\text { Lysis Time }\end{array}$ & a-Antitrypsin & Complement & Early Fate \\
\hline $\begin{array}{l}\text { Colectomy } 1 \\
\text { Colectomy } 2\end{array}$ & $\begin{array}{l}+550 \\
+187\end{array}$ & $\begin{array}{l}+880 \\
+180\end{array}$ & $\begin{array}{l}5-10 \\
5-20\end{array}$ & $\begin{array}{l}+700 \\
+280\end{array}$ & $\begin{array}{l}-66 \\
-50\end{array}$ & $\begin{array}{l}+250 \\
+300\end{array}$ & $\begin{array}{l}+40 \\
+40\end{array}$ & \\
\hline 1 L.C. & +250 & +330 & $5-20$ & +280 & +320 & +130 & -20 & $\begin{array}{l}\text { Rejection } \\
\text { at } 1 \text { day }\end{array}$ \\
\hline $\begin{array}{l}2 \text { T.L. } \\
3 \text { I.M. }\end{array}$ & $\begin{array}{l}+175 \\
-8\end{array}$ & $\begin{array}{l}+190 \\
-23\end{array}$ & $\begin{array}{l}5-10 \\
10-10\end{array}$ & $\begin{array}{l}+540 \\
+620\end{array}$ & $\begin{array}{l}\mathbf{0} \\
\mathbf{0}\end{array}$ & $\begin{array}{l}+175 \\
+140\end{array}$ & $\begin{array}{l}-20 \\
-78\end{array}$ & $\begin{array}{l}\text { Rejection } \\
\text { at } 5 \text { days }\end{array}$ \\
\hline $\begin{array}{l}4 \text { J.L. } \\
5 \text { J.S. }\end{array}$ & $\begin{array}{l}0 \\
+200\end{array}$ & $\begin{array}{l}+108 \\
+200\end{array}$ & $\begin{array}{l}10-20 \\
5-160\end{array}$ & $\begin{array}{r}+135 \\
+155\end{array}$ & $\begin{array}{l}-48 \\
+460\end{array}$ & $\begin{array}{r}+160 \\
+150\end{array}$ & $0^{-20}$ & $\begin{array}{l}\text { Lung } \\
\text { collapse }\end{array}$ \\
\hline 6 M.L. & -55 & +130 & $5-160$ & +230 & +270 & +250 & -25 & $\begin{array}{l}\text { Acute } \\
\text { tubular } \\
\text { necrosis at } \\
2 \text { days } \\
\text { Rejection } \\
\text { at } 6 \text { days }\end{array}$ \\
\hline 7 E.W. & +130 & +155 & $5-20$ & -60 & +600 & +200 & -75 & $\begin{array}{l}\text { Rejection } \\
\text { at } 10 \text { days }\end{array}$ \\
\hline 8 I.M. & -60 & -30 & $5-20$ & +180 & +290 & +180 & 0 & $\begin{array}{l}\text { Renal } \\
\text { cortical } \\
\text { necrosis at } \\
12 \text { days }\end{array}$ \\
\hline 9 J.M. & -60 & -90 & $20-160$ & -80 & -80 & +200 & 0 & $\begin{array}{l}\text { Rejection } \\
\text { at } 4 \text { days }\end{array}$ \\
\hline
\end{tabular}

Table II Early postoperative changes 1

${ }^{1}$ Percentage changes are given except for fibrin degradation products which are in $\mu \mathrm{g} / \mathrm{ml}$ absolute units (normal less than $20 \mu \mathrm{g} / \mathrm{ml}$ ).

'Had nephrectomy only 10 days before graft.

before the tenth day, and 10 rejection episodes occurred after the tenth day in seven patients.

\section{Results}

The more important protein changes which became evident in the postoperative period are given in Table II. These changes lasted for a period of 10 days and were therefore coincident by definition with early rejection episodes. As exemplified by the colectomy cases, the postoperative change consisted of a rise in fibrinogen and fibrin monomer together with a rise in fibrinolytic inhibitors and at the same time transient depression of plasminogen activator values as measured by the euglobulin lysis time. The levels of the reactive proteins- $\alpha$ l-antitrypsin, orosomucoid, and al-acid glycoprotein-also rose. The transplant patients tended to have similar changes but there were some outstanding differences. Table II shows that in four of the transplant patients the fibrinogen level actually fell, accompanied in three by a fall in fibrin monomer, and this happened in patients who, it was later realized, had developed rejection with renal ischaemic damage in the early postoperative phase. In this early phase complement as well as $\operatorname{lgM}$ declined in all the patients. At the 


\begin{tabular}{|c|c|c|c|}
\hline Case & $\begin{array}{l}\text { Fibrin } \\
\text { Degradation } \\
\text { Products } \\
(\mu g / m l)\end{array}$ & $\begin{array}{l}\text { Platelets } \\
(1,000 \text { per c. } \mathrm{mm})\end{array}$ & Complication \\
\hline $\begin{array}{l}\text { T.L. } \\
\text { I.M.L. } \\
\text { E.W. } \\
\text { I.M. } \\
\text { J.M. } \\
\text { R.W. }\end{array}$ & $\begin{aligned} & 5 \rightarrow 40 \\
& 5 \rightarrow 80 \\
& 20 \rightarrow 80 \\
& 5 \rightarrow 80 \\
& 5 \rightarrow 40 \\
& 2 \cdot 5 \rightarrow 80 \\
& 2 \cdot 5 \rightarrow 80 \\
& 1 \cdot 25 \rightarrow 10 \\
& 2 \cdot 5 \rightarrow 80 \\
& 5 \cdot 0 \rightarrow 40\end{aligned}$ & $\begin{array}{l}460 \rightarrow 330 \\
\overline{280} \rightarrow 200 \\
- \\
\overline{140} \rightarrow 90 \\
180 \rightarrow 90 \\
550 \rightarrow 80 \\
420 \rightarrow 270 \\
-\end{array}$ & $\begin{array}{l}\text { Rejection at } 3 \text { weeks } \\
\text { Pyrexia of unknown origin, myopathy at } 3 \text { months } \\
\text { Urine infection at } 3 \text { weeks } \\
\text { Rejection at } 4 \text { months } \\
\text { Rejection at } 6 \text { months } \\
\text { Rejection at } 6 \text { weeks } \\
\text { Rejection at } 8 \text { weeks } \\
\text { Renal cortical necrosis at } 2 \text { weeks } \\
\text { Rejection at } 2 \text { weeks } \\
\text { Rejection at } 2 \text { weeks }\end{array}$ \\
\hline
\end{tabular}

Table III Rejection after ten days

time of early recovery of renal function, fibrinolytic activator values of the transplant patients tended to rise from the previously depressed values of the chronic uraemic state.

Fibrin degradation products in the colectomy patients rose to about $20 \mu \mathrm{g} / \mathrm{ml}$ for 10 days and this slight rise also occurred in the transplant patients but four showed early peaking to $160 \mu \mathrm{g} / \mathrm{ml}$, the peak coinciding in patient J.S. with a postoperative collapse of the left lower lobe of the lung, in patient G.H. with suspected early rejection, in M.L. with acute tubular necrosis followed also by rejection, and in patient J.M. with rejection.

By the tenth day reactive protein changes were subsiding only to reappear as a sequel to episodes of rejection, extravasation of urine or urinary infection. Both serum complement and IgM were now rising unless a rejection episode occurred, when there was a fall followed by a rise. Six of the nine patients studied in detail and one other had some form of major crisis during this period, and it is of interest that these episodes were accompanied by a peak rise in the fibrin degradation products. These events are summarized in Table III. The value of the fibrin degradation products can be judged from the frequency with which they coincide with rejection. In all there were 22 episodes of fibrin degradation products peaking of which 10 (Table III) were part of a rejection, three were probably postoperative events, two might have been due to heparinization during rejection, three occurred after haemodialysis and two during coliform infections, one other was found in a patient (I.M.) who developed myositis with pyrexia of unknown origin, and a final one was unexplained. A rise in fibrin degradation products due to rejection was accompanied by a fall in the platelet count.

Apart from the transient recovery of fibrinolysis that appeared in the early postoperative period, there then followed a remarkable depression of fibrinolysis in all patients as summarized in Table IV. In three

\begin{tabular}{ll} 
& \\
\hline Patient & Activator Pattern \\
\hline L.C. & Depression \\
T.L. & Recovery peak $\rightarrow$ depression \\
I.M. & Peak $\rightarrow$ depression \\
J.L. & Depression \\
J.S. & Peak $\rightarrow$ depression \\
M.L. & Peak $\rightarrow$ depression \\
E.W. & Depression \\
I.M. & Peak $\rightarrow$ depression \\
J.M. & Depression \\
G.H. & Rise to normal levels \\
\hline
\end{tabular}

Table IV Fibrinolytic activator pattern during four weeks after graft

${ }^{1}$ Also illustrated in Figure 1.

patients depression of the euglobulin lysis time $\stackrel{\mathbb{Q}}{\mathscr{2}}$ preceded bad clinical rejection episodes (J.S. $24 \cdot 0 \overrightarrow{\vec{O}}$ units, F.M. 10.0 units, E.W. $4 \cdot 0$ units) but in others $\exists$ there was no relation to rejection.

When the patients were seen later as outpatients it was found that by two months of full ambulation the euglobulin lysis time usually returned to the normal range (40-110 units). However, it was less 3 than 40 units in 18 out of 50 random estimations in outpatients. Thus even later the euglobulin lysis time $\frac{3}{3}$ might be intermittently depressed and also at these times outpatients' fibrin degradation products might $\supset$ have risen to $40 \mu \mathrm{g} / \mathrm{ml}$, suggesting that the coincidence was a sign of insidious chronic $=$ rejection. Although fibrinolytic inhibitors showed their greatest values in the postoperative phase, they also continued intermittently at high levels in some patients.

Figure 1 gives in graphical form some of the details? of patient T.L. who illustrates typical features-the postoperative rise in fibrinogen, fibrin monomer, and al-antitrypsin, together with urokinase inhibitors. Note also the early recovery of the euglobulin lysis time followed by depression, and during this time a rejection episode was accompanied by a rise? in fibrin degradation products. Complement and $\varrho$ IgM are falling at about this time. 


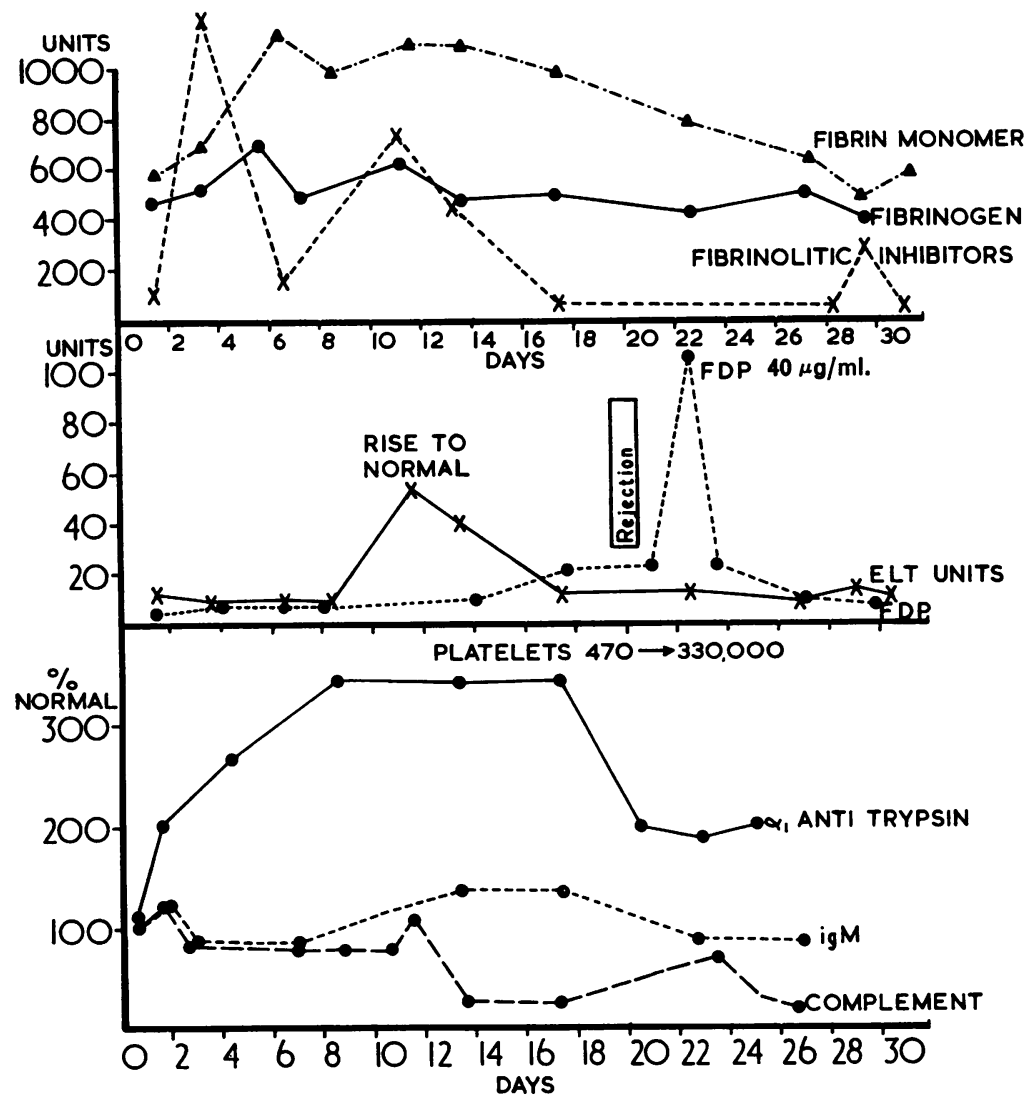

Fig. 1. Some typical features as shown in patient T.L.

\section{Discussion}

Our observation of serum protein reactive changes in the postoperative period agrees with previous studies (Crockson, Payne, Ratcliff, and Soothill, 1966; Werner, 1969, Werner and Cohnen, 1969). These are non-specific changes due to tissue damage or infection and although they may also occur as a sequel to rejection they are of no help in diagnosis. The already accepted indices of rejection, namely, decreased urine output and decreased urinary sodium with urinary excretion of alkaline phosphatases and LDH at the time of rise of the serum creatinine, leucocytosis, and graft swelling with tenderness, appear to be adequate (Bergström, Blomstrand, Magnusson, and Werner, 1968). However, as shown in Table II, a fall in plasma fibrinogen in the early postoperative period was associated with early rejection and ischaemic damage (cf McMillan, 1968). Moreover, a rise in serum fibrin degradation products when accompanied by a fall in platelets (Table III) was associated with rejection and was far more dramatic, albeit a later change, than a fall in complement or IgM (Zühlke, Deodhar, Nakamoto, and Kolff, 1967; Carpenter, Gill, Merrill, and Dammin, 1967).

A postoperative rise in fibrinolytic inhibitors is also recognized (Tsitouris, Bellet, Eilberg, Feinberg, and Sandberg, 1961) but is normally of limited duration. Fibrinolytic activator was markedly reduced for about eight weeks in our patients, apart from a transient return to normal levels at the time of initial urine production by the graft. Moreover, this could not be explained by inhibitor levels and suggested damage to endothelial cells with failure of production of activator. Inhibition of fibrinolysis for as long as two years has been described by Ljungqvist, Bergentz, Leondoer, and Nilsson (1969); these authors also suggest that antibodies might be produced against urokinase but we have been unable to detect such antibodies.

The endothelial cells of the normal kidney have a remarkable fibrinolytic potential (Holemans, Johnston, and Reddick, 1965) and there is some 
activity in normal arteriolar endothelium (Onoyama and Tanaka, 1969). It is possible that early loss of fibrinolysis might lead to a more serious type of rejection, as the findings in three of our patients suggest. In fact deposits of IgM and IgG, together with fibrin and complement, are now well recognized as occurring on renal endothelium during rejection (McKenzie and Whittingham, 1969), together with actual thrombi and progressing to later obliterative lesions in the form of 'endarteritis fibrosa' (Porter et al, 1967). Some of our outpatient results which showed a rise in fibrin degradation products at the time of inhibition of fibrinolysis seem to indicate this late type of chronic insidious rejection.

We are obliged to Professor D. N. S. Kerr for his continued interest and support. E.N.W. gratefully acknowledges a grant from the Medical Research Council and I.S.M. is supported by an MRC grant to Dr H. A. Dewar. Mr Alan Martin and Mr D. A. Piercy gave skilled technical assistance.

\section{References}

Bergström, K., Blomstrand, R., Magnusson, G., and Werner, B. (1968). Some laboratory data, including enzymatic observations, in human renal homotransplantation. Acta chir. scand., 134, 467-479.

Carpenter, C. B., Gill, T. J., III, Merrill, J. P., and Dammin, G. J. (1967). Instability of the complement system in patients with renal allografts. Transplantation, 5, 864-869.

Crockson, R. A., Payne, C. J., Ratcliff, A. P., and Soothill, J. F. (1966). Time sequense of acute phase reactive proteins following surgical trauma. Clin. chim. acta, 14, 435-441.

Holemans, R., Johnston, J. G., and Reddick, R. L. (1965). Release of plasminogen activator by the isolated perfused dog kidney. Nature (Lond.), 208, 291-292.

Isacson, S. (1970). Effect of prednisolone on the coagulation and fibrinolytic systems. Scand. J. Haemat., 7, 212-216.

Lipiński, B., Worowski, K., Jeljaszewicz, J., Niewiarowski, S., and
Rejniak, L. (1968). Participation of soluble fibrin monomon complexes and platelet factor 4 in the generalized Shwartzman. reaction. Thrombos. Diathes. haemorrh. (Stuttg.), 20, 285-29

Ljungqvist, U., Bergentz, S. E., Leandoer, L., and Nilsson, I. MD (1969). Coagulation and fibrinolysis after renal transplantation Scand. J. Urol. Nephrol., 3, 23-29.

McKenzie, I. F. C., and Whittingham, S. (1968). Deposits of immuno globulin and fibrin in human allografted kidneys. Lancet, $\overline{2}$ 1313-1316.

McMillan, R. (1968). Heparin in delayed transplant function. Lance $\mathbb{\triangle}$

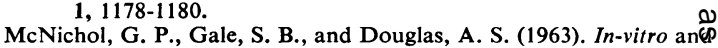
in-vivo studies of a preparation of urokinase. Brit. med. $J \cdot \overrightarrow{\mathrm{O}}$ 1, 909-915.

Mustard, J. F., Evans, G., Packham, M. A., and Nishizawa, E. E. (1969). Cellular and Humoral Mechanisms in Anaphyllaxis ando Allergy, pp. 151-163. Karger, Basle.

Onoyama, K., and Tanaka, K. (1969). Fibrinolytic activity of the arterial wall. Thrombos. Diathes. haemorrh. (Stuttg.), 21, 1-17

Porter, K. A. (1967). Rejection in treated renal allografts. J. clin. Pathin 20 (Suppl. 2), 518-534.

Porter, K. A., Dossetor, J. B., Marchioro, T. L., Peart, W. S., Renda iN J. M., Starzl, T. E., and Terasaki, P. I. (1967). Human renä transplants. I. Glomerular changes. Lab. Invest., 16, 153-18

Ratnoff, O. D., and Menzie, C. J. (1951). A new method for the determination of fibrinogen in small samples of plasma. LaD Clin. Med., 37, 316-320.

Tsitouris, G., Bellet, S., Eilberg, R., Feinberg, L., and Sandberg, tt (1961). Effects of major surgery on plasmin-plasminogen inhibitors. Arch. intern. Med., 108, 208-217.

Von Kaulla, K. N. (1963). In Chemistry of Thrombolysis: Huma Fibrinolytic Enzymes p. 79-80: Thomas, Springfield Ill.

Werner, M. (1969). Serum protein changes during the acute phase reaction. Clin. chim. acta, 25, 299-305.

Werner, M., and Cohnen, G. (1969). Changes in serum proteins in the immediate postoperative period. Clin. Sci., 36, 173-184.

Zühlke, V., Deodhar, S. D., Nakamoto, S., and Kolff, W. J. (1967 Serum immunoglobulin levels following human renal alls transplantation. Transplantation, 5, 135-141.

\section{Addendum}

Since this work was done it has been reporte (Isacson, 1970) that prednisone in a dose of $20 \mathrm{~m}$ per day is an inhibitor of plasminogen activate production. This could be the explanation for poof fibrinolysis in these patients. 